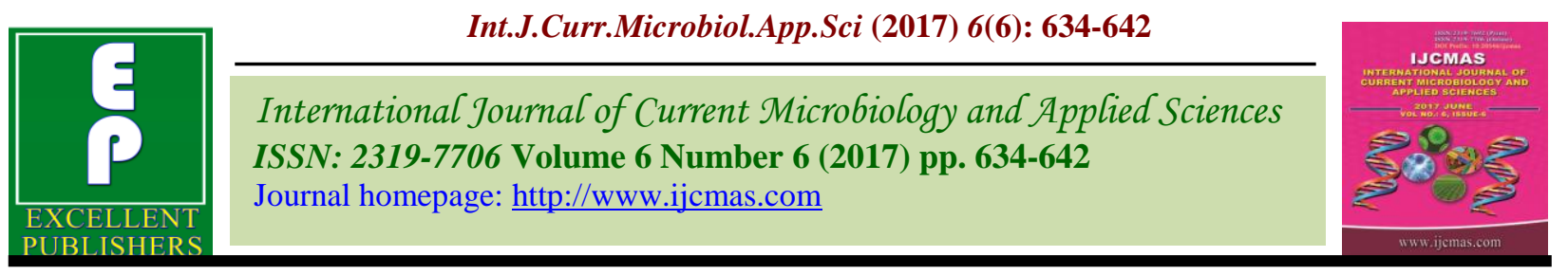

Original Research Article

https://doi.org/10.20546/ijcmas.2017.606.075

\title{
Performance Evaluation of Aggregatum Onion Genotypes (Allium cepa Var. Aggregatum) for Yield, Quality and Resistance Characters
}

\author{
K. Shoba Thingalmaniyan*, N. Rohini and T. Arumugam \\ Department of Vegetable Crops, Horticultural College and Research Institute, \\ Tamil Nadu Agricultural University, Coimbatore -641 003, Tamil Nadu, India \\ *Corresponding author
}

\begin{tabular}{|c|c|}
\hline & A B S T R A C T \\
\hline & \multirow{6}{*}{$\begin{array}{l}\text { Field experiment were conducted involving } 50 \text { aggregatum onion (Allium cepa var. } \\
\text { aggregatum) genotypes during } 2012-13,2013-14 \text { and } 2014-15 \text { at the experimental field of } \\
\text { College Orchard, Department of Vegetable Crops, Horticultural College and Research } \\
\text { Institute, Tamil Nadu Agricultural University, Coimbatore to identify the elite aggregatum } \\
\text { onion types for high yield and quality. Among the } 50 \text { aggregatum genotypes evaluated, } \\
\text { significant variations were observed for all the traits viz., plant height }(\mathrm{cm}) \text {, leaves per } \\
\text { plant, polar and equatorial diameter of bulbs ( } \mathrm{mm}) \text {, average clump weight }(\mathrm{g}) \text {, bulb colour, } \\
\text { total yield (t/ha) total soluble solids ( }{ }^{\circ} \text { brix) thrips damage }(\%) \text { and leaf spot incidence } \\
\text { (PDI). The per se performance of germplasm revealed that Aca } 15 \text { have excelled in yield } \\
\text { and contributing characters. On the basis of high per se performance, the potential } \\
\text { germplasm Aca } 15 \text { (Puttarsal local) recorded the highest plant height of } 38.40 \mathrm{~cm} \text {, number } \\
\text { of leaves (19.01), polar and equatorial diameter of bulbs was } 39.52 \text { and } 42.06 \mathrm{~mm} \text {, average } \\
\text { clump weight }(93.46 \text { g), total yield }(23.18 \text { t/ha) and total soluble solids }(18.69 \text { brix). } \\
\text { Lesser incidence of thrips damage }(9.1 \%) \text { and leaf spot incidence }(9.8 \%) \text { were also } \\
\text { recorded in Aca } 15 \text {. This germplasm could be tested in different seasons over different } \\
\text { locations for assessing their stability for high yield and quality. }\end{array}$} \\
\hline & \\
\hline $\begin{array}{l}\text { Small onion, } \\
\text { Yield, } \\
\text { Quality, } \\
\text { Mean perform } \\
\text { Selection. }\end{array}$ & \\
\hline Articl & \\
\hline $\begin{array}{l}\text { Accepted: } \\
\text { xx May } 2017 \\
\text { Available Online: } \\
\text { xx June } 2017\end{array}$ & \\
\hline & \\
\hline
\end{tabular}

\section{Introduction}

Onion (Allium cepa L.) belongs to the family Liliaceae, an important group of crops grown worldwide (Best, 2000). It is divided into three groups: Allium cepa, Allium cepa var. aggregatum, Allium proliferum, which are all diploids $(2 \mathrm{n}=2 \mathrm{x}=16)$ (Boukary et al., 2012).

The crop is a biennial herb of Central Asian origin (Afghanistan, Iran and Pakistan) and it is cultivated all around the world. Onion occupies 4th position in the world level after tomato, cabbage and watermelon with a global annual production of 25 million tonnes
(Boukary et al., 2012). Onion is a momentous source of vitamin $\mathrm{C}$ and potassium, contains about 60 calories in a medium-sized bulb and has very low sodium content. The bulbs provide $2.0 \mathrm{~g}$ protein, $72 \mathrm{mg}$ calcium and 54 mg phosphorus (Ado, 2001). It also contains vitamins viz., thiamine, riboflavin and niacin and is used for its medicinal value especially in the case of heart problems (Mettananda and Fordham, 2001).

The bulbs are major source of phytochemical called quercetin, which is effective in reducing the risk of cardiovascular disease, an 
anti-cancerous, and has promise to be an antioxidant The bulbs are boiled and used in soups and stews, fried or eaten raw in salads. It is hardy, bulbous rooted plant with small narrow rounded leaves and a white flower. Onion possesses typical pungent flavoring and it is useful mainly as a spice, seasoning and flavoring agent for foodstuff. Eating of raw onion boost the immune system and regulate blood sugar level.

In fact, successful onion production depends mainly on the selection of varieties that are adapted to different conditions imposed by specific environment. In Tamil Nadu, aggregatum onion is the most popularly grown by farmers, both for home use and source of income. Therefore, the introduction of new varieties represents an important axe to enhance production by increasing the number of cultivars available for growers, which is not only an advantage for the farming community but also for markets and processing industries. The potato onion or aggregatum onion (Allium cepa var. aggregatum) is a member of the onion family that reproduces primarily by division of bulbs, rather than by seed. Potato onions are more commonly grown by replanting the bulbs than by seed. The major aggregatum onion growing states of India are Tamil Nadu, Karnataka and Orissa. In Tamil Nadu, it is extensively cultivated in Coimbatore, Palladam, Perambalur, Trichy and Dindugul districts.

Onion (Allium cepa L.) is one of the important major vegetable crops in India. Plant breeders are primarily concerned with the improvement of quantitative and qualitative characters of any crop. This can be achieved by quantifying the genetic variation available for various characters of economic importance and inter-relationship among them. To improve the yield through selection of better varieties, knowledge on the nature of association of bulb yield with yield contributing characters is very essential. A cultivar crop performs differently under different agro-climatic conditions and various cultivars of the same species grown even in the same environment give different yields as the performance of a cultivar mainly depends on the interaction of genetic makeup and environment (Boukary et al., 2012). Ijoyah et al., (2008) evaluate the yield performance of four onion varieties and found that some other varieties performed better than the commonly grown onion varieties by the farmers. Tesfay et al., (2011) conducted an evaluation trial of three onion cultivars and concluded that onion cultivar performed differently and Parachinar local variety resulted in higher yield.

Hence, the present research was conducted to evaluate performance of fifty genotypes of aggregatum onion next to the commonly grown aggregatum onion varieties with the objective of identifying the variety/varieties with highest yield, quality, pest and disease resistant to replace or be used with the low yielding local variety under Tamil Nadu field conditions.

\section{Materials and Methods}

Field experiment was conducted in the college orchard, Horticultural College and Research Institute, Tamil Nadu Agricultural University, Coimbatore. The area is located on $11^{\circ} \mathrm{N}$ latitude and $77^{\circ} \mathrm{E}$ longitude and altitude of $426.26 \mathrm{~m}$ above mean sea level. The region belongs to sub tropical bioclimatic stage characterized by nice winter and cool summer. Fifty aggregatum onion germplasm were collected from various districts in Tamil Nadu and Gujarat. Details of the genotypes are furnished in table 1 . These 50 genotypes were evaluated and studied for their growth, yield and quality performance based on morphological and agronomical measurements (Fig. 1). The trial was started 
during 2012. Soil was cleared from weeds, rotovated and divided into beds on which well-decomposed farm yard manure was applied and incorporated manually into the soil. Each bed was divided into eight plots. The size of the plot was $3 \mathrm{~m} \times 1 \mathrm{~m}$ and the germplasms was planted in a randomized block design. The bulbs of each variety were sown on June 2012 -2014 in rows at spacing of $15 \mathrm{~cm}$ and a plant spacing of $10 \mathrm{~cm}$ in every variety is represented by 5 rows. Irrigation was done by drip irrigation and in advanced stage it was used for fertigation. Pre emergence weedicide spraying was done using pendimethalin $2 \mathrm{ml} /$ lit of water, followed by manual weeding. Harvesting was done when a large portion of the leaves were dry. Observations were recorded from 10 randomly selected plants of each germplasm and in each replication. Biometrical parameter includes plant height $(\mathrm{cm})$ and number of leaves. Bulb characteristics concerned polar diameter $(\mathrm{mm})$, equatorial diameter $(\mathrm{mm})$, average clump weight (g) and bulb colour. Yield and quality parameter like total yield (kg/ ha) and TSS ( ${ }^{\circ}$ Brix) were recorded. For identifying resistance sources, thrips damage and leaf spot incidence were also observed from 50 germplasms. The statistical parameters like mean, range were calculated as per the standard methods of analysis (Panse and Sukhatme, 1957).

\section{Results and Discussion}

Plant breeding programme of any crop aims at improving the existing types or evolving a new type which is superior to existing ones. Collection of genotypes from different geographical origin and evaluation for assessing the extent of variability are the first step in any crop improvement programme, as this offers a new broad genetic base population to make further selections (Robinson, 1965). To initiate selection and to facilitate varietal improvement, a study of yield related characteristics is a must. This will highlight the potentialities of wider varietal range either for direct introduction or to utilize these types as parents in future breeding programme.

In view of its potential cultivation in Tamil $\mathrm{Nadu}$, the present investigation was carried out with fifty cultivars of multiplier onion, collected from different sources. They were evaluated for yield, quality, pest and disease resistance. The data on growth, yield and its contributing characters and pest and disease resistance traits of the different onion cultivars recorded during the 2012-13, 201314 and 2014-15 are pooled and presented in table 2 .

Mean performance serves as an important criterion in eliminating the undesirable types in a selection programme. The results of the present investigation revealed that there exists significant difference for growth, yield and quality characters among the different cultivars of multiplier onion.

\section{Growth, Yield and Quality Characters}

The plant height was measured at the maturity stage and average was computed.

The pooled analysis of three year data showed there was a significant difference on the plant height due to genotypes (Table 2). The highest plant height $(38.70 \mathrm{~cm})$ was observed in Aca 12 (Sulur Pink type -1) and it was found at a par with the genotype Aca 15 $(38.40 \mathrm{~cm})$ whereas the lowest plant height $(22.10 \mathrm{~cm}$ ) was recorded by Aca 3 (Dindigul type-1). Similar variability in plant height between varieties confirming there results were observed on onion (Ibrahim, 2010; Trivedi and Dhumal, 2010). According to Mohanty and Prusti (2001), the difference in height of the plant on onion is mainly attributed to the genetic potential but also to 
environmental factors especially temperature and photoperiod (Tesfay et al., 2011). These results of current investigation are in agreement with Azoom et al., (2014). Number of leaves influences the yield to a significant extent also decide the spread of the plant. The number of leaves was more in the genotype Aca 49 (20.40) and it was found on par with the genotype Aca 15 (20.34) whereas lowest leaves (9.4) were recorded on Aca 38 (Natagarh local 03). The variation in number of branches per plant might have been due to own genetic makeup and also due to plant height. Boukary et al., (2012) and Dwivedi et al., (2012), observed the difference in production of leaves between varieties of onion and attributed this difference mainly to the cultivar, but other researchers confirmed that environmental conditions (Ijoyah et al., 2008) in which plant growth contribute to the development of leaves on plant.

Table.1 Details of aggregatum onion Germplasm collected from Tamil Nadu and Gujarat

\begin{tabular}{|c|c|c|c|}
\hline Code & Source & Code & Source \\
\hline Aca 1 & Coimbatore Local White & Aca 26 & Sandhaipadugai Pink type-1 \\
\hline Aca 2 & Oddanchatram & Aca 27 & Sandhaipadugai White type- 2 \\
\hline Aca 3 & Dindigul type -1 & Aca 28 & Gnanamedu White type- 1 \\
\hline Aca 4 & Coimbatore Local Pink & Aca 29 & Sandhaipadugai White type- 1 \\
\hline Aca 5 & Dindigul type -2 & Aca 30 & Dhenkanal local 02 \\
\hline Aca 6 & Rasipuram & Aca 31 & Anugul local 09 \\
\hline Aca 7 & Salem & Aca 32 & Keonjhar local 07 \\
\hline Aca 8 & Gnanamedu Pink type -1 & Aca 33 & Anugul local 06 \\
\hline Aca 9 & Gnanamedu type - 1 & Aca 34 & Dhenkanal local 01 \\
\hline Aca 10 & Gnanamedu type - 2 & Aca 35 & Balasore local 02 \\
\hline Aca 11 & Gnanamedu type - 3 & Aca 36 & Keonjhar local 04 \\
\hline Aca 12 & Sulur Pink type -1 & Aca 37 & Keonjhar local 06 \\
\hline Aca 13 & Gnanamedu type - 4 & Aca 38 & Natagarh local 03 \\
\hline Aca 14 & Mettukadai & Aca 39 & Keonjhar local 05 \\
\hline Aca 15 & Puttarsal & Aca 40 & Ganjan local 01 \\
\hline Aca 16 & Sandhaipadugai Pink type-3 & Aca 41 & Anugul local 08 \\
\hline Aca 17 & $\mathrm{CO}(\mathrm{On})-5$ & Aca 42 & Natagarh local 04 \\
\hline Aca 18 & Sandhaipadugai Pink type- 2 & Aca 43 & Keonjhar local 01 \\
\hline Aca 19 & Gnanamedu Pink type - 2 & Aca 44 & Keonjhar local 02 \\
\hline Aca 20 & Sandhaipadugai Pink type- 4 & Aca 45 & Keonjhar local 03 \\
\hline Aca 21 & Sandhaipadugai Pink type- 5 & Aca 46 & Mayurbhanji local 01 \\
\hline Aca 22 & C.Mutlur & Aca 47 & Khurda local 01 \\
\hline Aca 23 & Sultanpet Pink & Aca 48 & Khurda local 02 \\
\hline Aca 24 & Thottapadi Pink & Aca 49 & Nayagarh local 01 \\
\hline Aca 25 & Gnanamedu Pink type - 3 & Aca 50 & Balasore local 01 \\
\hline
\end{tabular}


Table.2 Performance of aggregatum onion genotypes for yield and quality traits

\begin{tabular}{|c|c|c|c|c|c|c|c|c|c|c|}
\hline Accessions & $\begin{array}{l}\text { Plant } \\
\text { height } \\
(\mathrm{cm})\end{array}$ & $\begin{array}{l}\text { No. of } \\
\text { leaves }\end{array}$ & $\begin{array}{l}\text { Polar } \\
\text { dia. } \\
(\mathrm{mm})\end{array}$ & $\begin{array}{l}\text { Equato } \\
\text { rial dia. } \\
(\mathrm{mm})\end{array}$ & $\begin{array}{l}\text { Average } \\
\text { clump } \\
\text { weight } \\
\text { (g) }\end{array}$ & $\begin{array}{l}\text { Bulb } \\
\text { colour }\end{array}$ & $\begin{array}{l}\text { Total } \\
\text { yield } \\
\text { (t/ha) }\end{array}$ & $\begin{array}{l}\text { TSS } \\
(\%)\end{array}$ & $\begin{array}{l}\text { Thrips } \\
\text { damag } \\
\text { e }(\%)\end{array}$ & $\begin{array}{l}\text { Leaf } \\
\text { spot } \\
\text { (PDI) }\end{array}$ \\
\hline Aca 1 & 33.17 & 14.07 & 16.30 & 20.63 & 61.00 & white & 18.20 & 15.20 & 26.3 & 8.5 \\
\hline Aca 2 & 28.03 & 10.70 & 18.40 & 22.80 & 69.70 & white & 17.90 & 14.97 & 29.7 & 22.8 \\
\hline Aca 3 & 22.10 & 10.97 & 16.10 & 21.23 & 69.00 & pink & 15.80 & 14.93 & 30.1 & 15.7 \\
\hline Aca 4 & 24.20 & 9.43 & 25.57 & 29.63 & 80.30 & pink & 14.80 & 15.70 & 27.3 & 21.0 \\
\hline Aca 5 & 25.77 & 10.87 & 23.27 & 28.30 & 74.20 & pink & 13.77 & 15.10 & 10.8 & 11.1 \\
\hline Aca 6 & 36.00 & 17.17 & 16.63 & 21.70 & 65.60 & pink & 14.30 & 15.80 & 26.4 & 19.5 \\
\hline Aca 7 & 31.50 & 16.23 & 15.90 & 22.47 & 83.70 & pink & 17.67 & 16.03 & 17.1 & 14.8 \\
\hline Aca 8 & 36.17 & 14.20 & 22.30 & 27.10 & 79.50 & pink & 17.70 & 16.87 & 20.2 & 26.1 \\
\hline Aca 9 & 34.58 & 18.27 & 32.47 & 38.51 & 86.54 & pink & 21.04 & 17.05 & 18.5 & 13.7 \\
\hline Aca 10 & 29.80 & 9.83 & 26.50 & 26.10 & 68.60 & pink & 16.23 & 17.23 & 18.7 & 18.1 \\
\hline Aca 11 & 30.03 & 11.37 & 27.53 & 27.77 & 67.20 & pink & 17.90 & 14.83 & 21.7 & 11.5 \\
\hline Aca 12 & 38.70 & 12.27 & 35.93 & 34.57 & 71.50 & pink & 16.13 & 18.13 & 19.1 & 16.2 \\
\hline Aca 13 & 34.43 & 13.70 & 31.50 & 31.87 & 81.10 & pink & 15.47 & 16.20 & 13.1 & 14.8 \\
\hline Aca 14 & 36.93 & 14.40 & 32.13 & 27.87 & 82.10 & pink & 14.60 & 16.17 & 29.6 & 15.2 \\
\hline Aca 15 & 38.40 & 19.01 & 39.52 & 42.06 & 93.46 & pink & 23.18 & 18.69 & 9.1 & 9.8 \\
\hline Aca 16 & 36.63 & 14.27 & 30.80 & 33.67 & 77.60 & pink & 14.50 & 17.97 & 18.4 & 16.5 \\
\hline Aca 17 & 35.20 & 15.40 & 30.07 & 31.27 & 69.60 & pink & 16.23 & 15.87 & 19.5 & 16.3 \\
\hline Aca 18 & 27.30 & 13.43 & 26.37 & 27.77 & 66.00 & pink & 14.57 & 16.73 & 23.2 & 12.7 \\
\hline Aca 19 & 34.17 & 12.70 & 30.00 & 32.93 & 60.80 & pink & 15.23 & 16.97 & 27.6 & 21.9 \\
\hline Aca 20 & 29.17 & 10.20 & 25.53 & 28.33 & 77.20 & pink & 16.00 & 17.40 & 15.6 & 22.8 \\
\hline Aca 21 & 27.50 & 11.60 & 26.90 & 28.93 & 75.90 & pink & 16.43 & 16.43 & 27.6 & 11.8 \\
\hline Aca 22 & 28.23 & 11.87 & 28.93 & 27.47 & 74.90 & pink & 13.03 & 16.70 & 19.1 & 11.1 \\
\hline Aca 23 & 29.10 & 9.83 & 29.07 & 33.57 & 74.20 & pink & 12.63 & 18.87 & 10.9 & 12.1 \\
\hline Aca 24 & 30.33 & 16.17 & 31.10 & 35.70 & 86.20 & pink & 13.90 & 18.83 & 16.7 & 15.3 \\
\hline Aca 25 & 37.63 & 15.80 & 28.57 & 24.27 & 85.10 & pink & 15.70 & 19.47 & 26.7 & 16.3 \\
\hline Aca 26 & 27.37 & 13.77 & 33.10 & 32.80 & 83.20 & pink & 13.00 & 17.83 & 27.8 & 15.7 \\
\hline Aca 27 & 27.53 & 16.07 & 29.57 & 31.03 & 85.70 & white & 17.23 & 14.60 & 17.2 & 22.7 \\
\hline Aca 28 & 24.40 & 11.70 & 25.77 & 34.17 & 65.80 & white & 12.00 & 14.93 & 13.1 & 9.8 \\
\hline Aca 29 & 31.13 & 12.20 & 28.53 & 32.40 & 70.50 & white & 12.20 & 15.77 & 17.9 & 9.5 \\
\hline Aca 30 & 26.37 & 11.40 & 25.07 & 39.90 & 65.80 & pink & 12.43 & 17.73 & 26.4 & 14.8 \\
\hline Aca 31 & 34.00 & 12.57 & 29.37 & 35.60 & 71.10 & pink & 14.00 & 17.97 & 18.3 & 13.6 \\
\hline Aca 32 & 31.47 & 11.33 & 29.47 & 31.73 & 63.40 & pink & 10.53 & 16.93 & 26.7 & 19.7 \\
\hline Aca 33 & 37.10 & 11.57 & 31.77 & 34.93 & 66.20 & pink & 12.70 & 18.43 & 18.4 & 15.7 \\
\hline
\end{tabular}




\begin{tabular}{|c|c|c|c|c|c|c|c|c|c|c|}
\hline Aca 34 & 34.37 & 10.13 & 30.33 & 32.03 & 73.40 & pink & 12.57 & 18.87 & 17.0 & 15.9 \\
\hline Aca 35 & 38.30 & 9.60 & 33.30 & 35.70 & 80.30 & pink & 15.57 & 18.30 & 19.1 & 15.9 \\
\hline Aca 36 & 29.00 & 10.57 & 26.70 & 26.53 & 71.80 & pink & 12.07 & 15.10 & 27.6 & 17.6 \\
\hline Aca 37 & 34.10 & 17.47 & 30.73 & 27.30 & 65.80 & pink & 14.63 & 13.77 & 29.7 & 21.0 \\
\hline Aca 38 & 29.37 & 9.40 & 27.93 & 31.47 & 57.90 & pink & 9.30 & 16.20 & 13.9 & 19.5 \\
\hline Aca 39 & 28.00 & 9.50 & 24.97 & 23.60 & 55.50 & pink & 11.33 & 17.80 & 27.7 & 18.7 \\
\hline Aca 40 & 30.13 & 10.23 & 26.70 & 26.33 & 60.70 & pink & 11.80 & 19.77 & 27.6 & 21.9 \\
\hline Aca 41 & 31.07 & 20.23 & 28.33 & 29.70 & 75.50 & pink & 13.83 & 20.73 & 19.5 & 21.9 \\
\hline Aca 42 & 27.70 & 16.13 & 24.37 & 29.00 & 78.50 & pink & 14.60 & 21.00 & 21.2 & 19.7 \\
\hline Aca 43 & 29.17 & 17.67 & 25.23 & 25.33 & 78.10 & pink & 12.70 & 18.87 & 19.0 & 23.4 \\
\hline Aca 44 & 29.97 & 17.53 & 25.23 & 30.13 & 60.20 & pink & 12.73 & 20.13 & 25.8 & 26.2 \\
\hline Aca 45 & 25.07 & 17.13 & 23.70 & 34.33 & 72.80 & pink & 13.20 & 21.77 & 18.8 & 16.6 \\
\hline Aca 46 & 29.20 & 17.80 & 26.20 & 30.17 & 50.40 & pink & 9.57 & 22.07 & 16.1 & 13.2 \\
\hline Aca 47 & 30.63 & 19.03 & 14.97 & 31.07 & 53.10 & pink & 10.77 & 20.93 & 27.3 & 18.1 \\
\hline Aca 48 & 30.10 & 17.67 & 15.80 & 32.33 & 54.50 & pink & 11.50 & 18.50 & 19.9 & 16.2 \\
\hline Aca 49 & 34.13 & 20.40 & 13.67 & 30.33 & 86.00 & pink & 17.80 & 15.70 & 23.4 & 17.8 \\
\hline Aca 50 & 30.53 & 17.37 & 15.77 & 30.23 & 66.80 & pink & 16.20 & 14.53 & 17.2 & 15.1 \\
\hline S.Ed & 0.67 & 0.76 & 1.04 & 0.73 & 1.60 & - & 0.48 & 0.34 & 0.97 & 1.21 \\
\hline CD $(0.5)$ & 1.34 & 1.49 & 2.05 & 1.43 & 3.10 & - & 0.95 & 0.66 & 1.91 & 2.48 \\
\hline CV & 2.64 & 6.80 & 5.00 & 3.04 & 2.70 & - & 4.08 & 2.41 & 10.22 & 9.87 \\
\hline
\end{tabular}

Fig.1 Evaluation of aggregatum onion genotypes - Field view

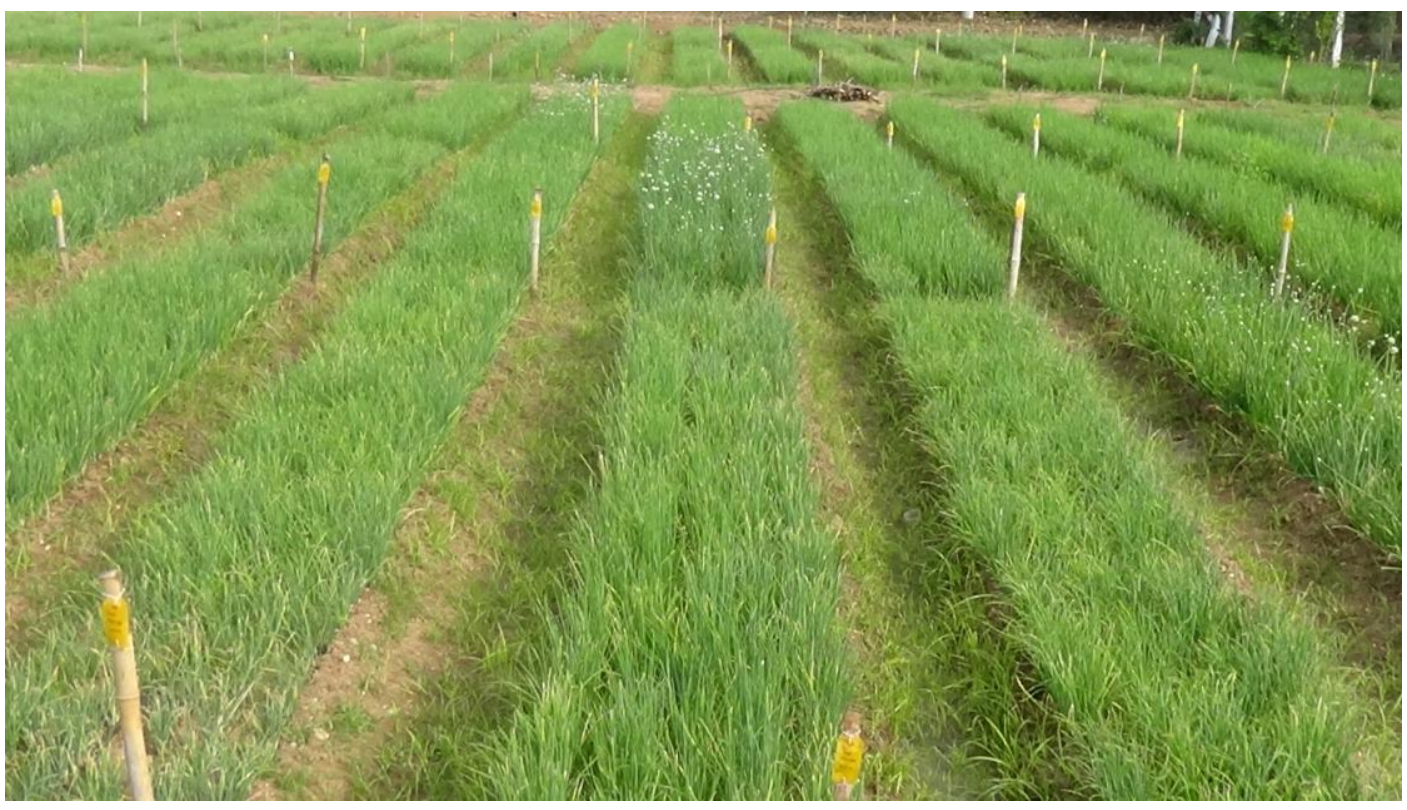


Fig.2 Promising genotypes based on yield, quality and resistance characters

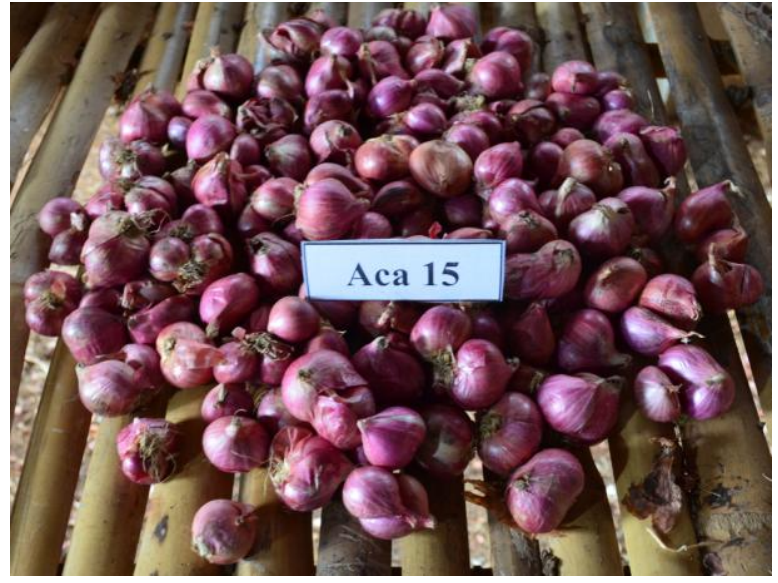

Aca 15 (Puttarsal local type)

Polar diameter (thickness) in onion is an important character, because it indicates bulb storage ability. The onion with thin polar diameter, store better than skin diameter of bulbs. There was significance difference on polar diameter of bulb due to genotypic effect. The highest mean polar diameter (39.52 mm) was found on Puttarasal local and lowest $(13.47 \mathrm{~mm})$ was found on Nayagarh local 01 . These results are in agreement with the results of the study conducted by Gautam et al., (2006) and Azoom et al., (2014). The lowest average equatorial diameter of 20.63 $\mathrm{mm}$ was recorded in Coimbatore Local White (Aca1) and highest equatorial diameter of $42.06 \mathrm{~mm}$ was found on Aca 15 (Puttarsal local). Furthermore, there was no toppling and sunken of neck in Aca 15. Thamburaj et al., (1976) stated that increased bulb diameter gave higher yield in onion. Singh (1990) also indicated the importance of bulb diameter for higher bulb yield. Similarly, analogous data were founded for diameter of bulb by Moulin et al., (2012) working on different varieties of melon, tomato, pepper and potato.

Yield is a complex trait influenced by many factors. In onion, the important yield contributing characters are mean weight of bulblets and bulb diameter. In the present

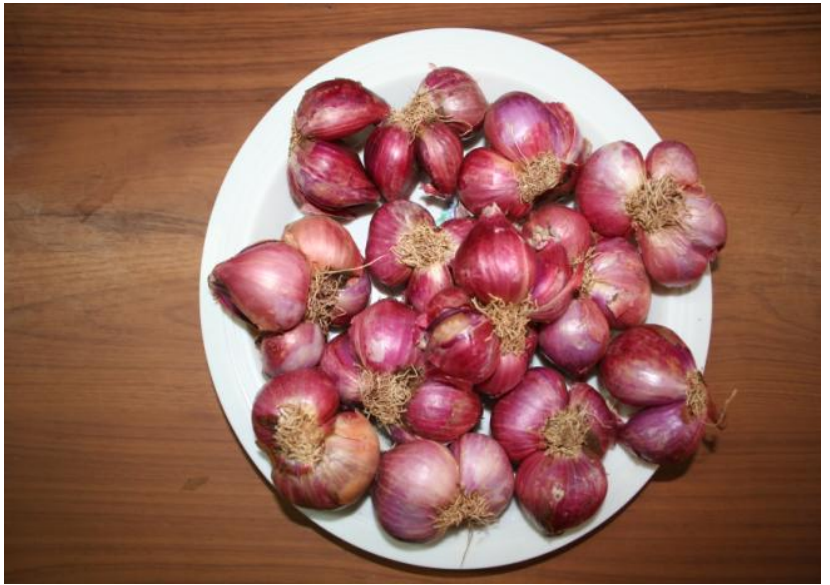

Aca 9 (Gnanamedu type - 1)

experiments, significant variation in bulblet weight was noticed. The importance of bulblet weight as an important yield component has been reported by Padda et al., (1973). Clump weight is the most important component that contributes directly to the yield in aggregatum onion. Among fifty genotypes, Aca 15 (Puttarsal) registered the highest average clump weight of $93.46 \mathrm{~g}$ and lowest clump weight (50.4 g) was recorded in Aca 46 (Mayurbhanji local 01). The highest clump weight in this genotype may be due to its genetic character and adaptability to agroclimatic conditions by the place of the experiment. Results of this study are in accordance with the findings of Boukary et al., (2012); Moulin et al., (2012). In onion bulb colour important character because it decide the consumer preference. Among the fifty genotypes evaluated five genotypes (Aca 1, Aca 2, Aca 27, Aca 28 and Aca 29) recorded white colour bulbs and remaining genotypes registered pink colour bulbs. The difference in the bulb of genotypes is due to their genetic nature. These results were in conformity with the findings of RiveraMartinez et al., 2005, Nilufar, 2009, Boukary et al., 2012 and Azoom et al., (2014). Yield is a composite character and is dependent on many constituent traits. Any change in these 
constituent traits would reflect on total yield. Except Aca 15 (Puttarsal) and Aca 9 (Gnanamedu type - 1) all the genotypes recorded yield of less than 20 tonnes/ha and Aca 15 (23.18 t/ha) and Aca 9 (21.04 t/ha) recorded the highest total yield. The variation in yield might have been due to clump weight, diameter of bulbs, genetic nature and environmental factor.

The recorded variations of varieties in marketable yield could be due to their differences in genetic make-up (Pavlovic et al., 2003) and agro ecological adaptations.

The quality parameters, viz., TSS, ascorbic acid and pyruvic acid contents mainly decide the quality and nutritive value of onion bulbs. Total soluble solids, an important quality criterion for onions, contribute towards flavours (Sharma et al., 1996) and processing quality. The soluble solid content would ultimately decide the dry matter that in turn would reflect on the recovery of processed products. In the present investigations, the parents, Aca 46 (22.07 ${ }^{\circ}$ brix) and Aca 45 $\left(21.77^{\circ}\right.$ brix $)$ registered comparatively higher TSS content. The higher TSS value in these genotypes may be due to its inherent characteristics. Similar results were observed by Pavlovic et al., 2003.

\section{Resistance to pest and diseases}

The major reasons for the low productivity of onion are the paucity of varieties adapted to different agro-climatic situations and growing conditions and the incidence of pests and diseases. Among the pests, onion thrips is important and it is not only a damaging pest but also act as a vector for viral diseases. Among the genotypes screened, Aca 15 (9.1\%) recorded the lowest per cent of thrips damage, while Aca 3 (30.1\%) recorded the highest per cent of thrips damage. Hence, use of tolerant varieties is the simplest and more convenient method of pest control.
Among the major constraints in the production of onion, leaf spot is very deleterious causing considerable damage to the crop both in yield and quality of the produce. Among genotypes, Aca 1 (8.5 per cent) recorded significantly low leaf spot damage followed by Aca 29 (9.5 per cent) and Aca 15 (9.8 per cent) compared to other lines. The disease is prevalent in almost all the major onion growing areas of India.

Based on the present results, it can be concluded that the onion varieties studied can be easily differentiated from one another due to their distinctive morphological characters and their performance under Coimbatore condition. The local varieties 'Aca 15 (Puttarsal) and Aca 9 (Gnanamedu type - 1) performed best and recommended as a potential replacement to the low yielding variety under field conditions in Coimbatore region of Tamil Nadu (Fig. 2). This is associated with a higher number of leaves, diameter of bulbs, clump weight and yield and resistant to pest and disease respectively. It is however recommended that further investigation on the yield performance and nutritional quality of the varieties be evaluated across different locations with varied ecology in Tamil Nadu.

\section{References}

Azoom, Kaouther Zhani, Cherif Hannachi., 2014. Performance of Eight Varieties of Onion (Allium cepa L.) Cultivated under Open Field in Tunisia. Notulae Scientific Biologicae 6(2): 220-224

Boukary H, Haougui, A., Barage, M., Adam, T., Roumba, A., Saadou, M., 2012. Evaluation agro-morphology of onion varieties under ecotypes of Nigeria. International Journal of Biological and Chemistry Science, 6(6): 3098-3106.

Budhathoki, K., 1997. The effects of environmental conditions on the growth and development of onions (Allium cepa, L.) in Nepal. Ph.D. Thesis. Department of Agriculture and 
Horticulture, Wye College, University of London.

Dwivedi, Y.C., Kushwah, S.S., Sengupta, S.K., 2012. Evaluation of onion varieties for growth, yield and quality traits under agroclimatic conditions of kymore plateau region of Madhya Pradesh, India. Agricultural Science Digest, 32(4): 326-328.

Gautam, I.P, Bhogendra Khatri., Govinda P. Paudel., 2006. Evaluation of Different Varieties of Onion and Their Transplanting Times for OffSeason Production in Mid Hills of Nepal. Nepal Agricultural Research Journal, 7: 2126.

Ibrahim, N.D., 2010. Growth and yield of Onion (Allium cepa L.) in Sokoto. Nigeria Agricultural Biological Journal, 4: 556-564.

Ijoyah, M.O, Rakotomavo, H., Naiken, M.V. 2008. Yield performance of four onions (Allium cepa L.) varieties compared with the local variety under open field conditions at Anse Boileau, Seychelles. Journal of Science and Technology, 28(3): 28-33.

Lao, P.D. 2002. Evaluation Trial of Promising Onion Lines. Asian Vegetable Research Development Centre -ARC Research Report, Pp. 5-9.

Mettananda, K.A., Fordham, R. 2001. The Effects of Plant Size and Leaf Number on the Bulbing of Tropical Short-day Onion Cultivars (Allium cepa L.) Under Controlled Environments. Journal of Horticultural Science, 14(5): 22-31.

Moamogwe, M. 2001. Comparative Performance of Three Onion Varieties to Different Application Rates of Poultry Manure in Rundu, Namibia. Netherlands Journal of Agricultural Science, 40:101-104.

Mohanty, B.K, Prusti, A.M. 2001. Performance of common onion varieties in Kharif seasons. Journal of Tropical Agriculture, 39: 21-23.
Moulin, M.M., Rodrigues, R., Goncalves, Sudre, C.P., Dos Santo, Silva. 2012. Collection and morphological characterization of sweet potato landraces in North of Rio de Janeiro state. Horticultural Brassicae, 30(2): 286-292.

Nilufar, Y, 2009. Morphological characterization and genetic diversity of onion (Allium cepa L.). M.Sc., Thesis, Faculty of Agriculture, Sher-E-Bangla Agricultural University, Dhaka, 71pp.

Pavlovic, N., Zecevic, B., Zdravkovic, M., Ivanovic, M., Damjanovic, M. 2003. Variability and heritability of average yield of onion bulb (Allium cepa L.). Genetics, 35(3): 149-154.

Robinson, H.F. 1965. Quantitative genetics in relation to breeding on centennial of Mendelism. Indian Journal of Genetics, 26(4): 171-187.

Sharma, S., Bal, S.S. and Bajaj, K.L. 1996. Chemical composition of some important varieties of onion (Allium cepa L.). Vegetable Science, 23(1): 48-51.

Singh, B.D. 1990. Plant Breeding, Kalyani Publishers, New Delhi. pp.130.

Tesfay, S.Z., Bertling, I., Odindo, A.O., Greenfield P.L., Workneh T.S. 2011. Growth responses tropical onion cultivars to photoperiod and temperature based on growing degree days. African Journal of Biotechnology, 10 (71): 15875-15882.

Thamburaj, S., Gnanamurthy, P. and Shanmugasubramaniam, A. 1976. Association of biometric Traits in Onion (Allium cepa L.). South Indian Horticulture, 24: 62-63.

Trivedi, A.P., Dhumal K.N. 2010. Variability and correlation studies on bulb yield, morphological and storage characters in onion (Allium cepa L.). Journal of Pure and Applied Sciences, 18: 1-4.

\section{How to cite this article:}

Shoba Thingalmaniyan, K., N. Rohini and Arumugam, T. 2017. Performance Evaluation of Aggregatum Onion Genotypes (Allium cepa Var. Aggregatum) for Yield, Quality and Resistance Characters. Int.J.Curr.Microbiol.App.Sci. 6(6): 634-642.

doi: https://doi.org/10.20546/ijcmas.2017.606.075 